\title{
Pengembangan Pariwisata Berbasis Desa Adat di Desa Penglipuran Kabupaten Bangli
}

\author{
A.A Sri Agung Pradnyaparamita \\ Program Studi Antropologi \\ [agungpradnyaparamita@gmail.com]
}

\begin{abstract}
Traditional village-based tourism development in the village of Bangli Regency Penglipuran a tourism development conducted by the Village Penglipuran. The problems of this study include (1) the form of traditional village-based tourism development and (2) the impact of tourism development based Indigenous Village. The research objective is (1) determine the form of the traditional village-based tourism development and (2) reveal how far the impact of developing a traditional village-based tourism. The method used in this research is descriptive qualitative method. Data collection techniques including observation, interview, literature study and documentation. Data analysis was performed through three simultaneous flow of activities, namely data reduction, data presentation, and conclusion. The theory used is the theory of community-based tourism and tourism impact theory. Results of this study are as follows. Traditional village-based tourism development in the village Penglipuran include tourist attraction in the village Penglipuran, the shape of the traditional village-based tourism development, and the role of indigenous villages in Penglipuran village tourism development. The impact of the traditional village-based tourism development in the village Penglipuran includes the impact of tourism on the physical environment and the natural, social, cultural, and economic. Conclusions This study is the first, the form of the traditional village-based tourism development in the village Penglipuran managing entity called Rural Tourism Organization business Penglipuran. This institution gives a role to the traditional village as the board of supervisors and the traditional village also has the authority to decide all matters related to the development of tourism. Second, the impact of the traditional village-based tourism development in the village Penglipuran the form of positive and negative impacts on the physical environment and the natural, social, cultural, and economic.
\end{abstract}

Keywords: Tourism Development, The Village People, Indigenous Institute

\section{Latar Belakang}

Bali dengan potensi budaya yang dimiliki telah dijadikan salah satu tempat pengembangan pariwisata. Menurut Perda Provinsi Bali Nomor 2 Tahun 2012 tentang Kepariwisataan Budaya, disebutkan bahwa pembangunan pariwisata budaya Bali diarahkan untuk meningkatkan kesejahteraan masyarakat serta melestarikan lingkungan. Pembangunan pariwisata juga ditujukan untuk mengembangkan dan mendayagunakan potensi kepariwisataan daerah dan meningkatkan peran serta masyarakat (Biro Humas \& Protokol Setwilda Tingkat I, 1998: 17-18). Terkait pengembangan potensi daerah, Pemerintah Kabupaten Bangli mengeluarkan Surat Keputusan Bupati Kepala Daerah Tingkat II Bangli Nomor 115 Tahun 1993 tentang penetapan objek-objek wisata Daerah Kabupaten Bangli, dan salah satu Desa yang ditetapkan sebagai daya tarik wisata adalah Desa Adat/Pakraman Penglipuran.

Desa Penglipuran merupakan salah satu Desa Bali Aga yang berada di Kelurahan Kubu, Kecamatan Bangli, 
Kabupaten Bangli. Menurut Reuter (2005: 18), Desa Bali Aga merupakan wilayah yang terletak di daerah pegunungan dan didiami oleh kelompok etnis minoritas. Ciri-ciri Desa Bali Aga adalah kehidupan komunal, susunan pengurus ulu apad, dan adanya konsep luan teben (Dwijendra, 2009: 9). Sebagai Desa Bali Aga, Desa Penglipuran memiliki keunikan baik dari segi fisik, ekologi, kehidupan sosial budaya, dan tradisi. Keunikan-keunikan tersebut merupakan potensi yang dikembangkan sebagai daya tarik wisata.

Pengembangan pariwisata di Desa Penglipuran dilakukan dengan lebih mengedepankan peran serta desa adat. Pengembangan pariwisata dengan melibatkan desa adat merupakan pengejawantahan dari konsep kebijakan pembangunan pariwisata berdimensi kerakyatan. Wacana pembangunan berwawasan kerakyatan merupakan reaksi terhadap kebijakan pembangunan konglomerasi yang selama ini lebih berpihak pada pemilik modal yang bukan berasal dari anggota masyarakat setempat. Pembangunan berwawasan kerakyatan lebih mengedepankan peningkatan ekonomi rakyat dan pemberdayaan masyarakat. Para pemikir pembangunan pedesaan telah menyadari bahwa pembangunan konglomerasi seringkali merugikan masyarakat setempat. Masyarakat sebagai pemilik sah sumber daya setempat kerap mengalami marginalisasi sehingga kualitas hidupnya justru menurun dibandingkan sebelum adanya pembangunan. Atas dasar itu beberapa ahli menekankan pentingnya pembangunan sebagai social learning dan pembangunan harus mulai dari bawah (buttom up). Menurut Korten (Pujaastawa, 2009: 30), pembangunan dengan paradigma ini menuntut adanya partisipasi masyarakat lokal dalam berbagai tahap pembangunan, sehingga pengelolaan pembangunan benar-benar dilakukan oleh mereka yang hidup dan kehidupannya dipengaruhi oleh pembangunan tersebut atau apa yang dikenal dengan community based resource management atau community management.

Dalam pengembangan pariwisata, masyarakat Desa Penglipuran sebagai Desa Bali Aga tetap mempertahankan nilai dan norma yang mengatur kehidupan masyarakat setempat. Menurut Koentjaraningrat (2003: 76) sistem nilai budaya adalah tingkat tertinggi dan paling abstrak dari adat-istiadat karena nilai budaya terdiri atas konsep-konsep mengenai segala sesuatu yang dinilai berharga dan penting oleh masyarakat sehingga dapat berfungsi sebagai pedoman pada kehidupannya. Hal ini tampak pada berbagai aturan yang diterapkan di Desa Penglipuran, seperti tidak diperbolehkan menjual tanah karena tanah tersebut adalah milik desa; tidak diperbolehkan membuat bangunan bertingkat; dilarang menebang pohon tanpa seijin desa; bagi wisatawan yang ingin mengunjungi Pura Penataran harus mentaati aturan yang ditetapkan seperti mengenakan selendang dan tidak memasuki pura pada saat menstruasi; dan wisatawan juga diharapkan tidak mengunjungi tempat-tempat sakral melewati waktu yang ditentukan.

Dari penjelasan di atas ada dua hal yang dapat dilihat dari pengembangan pariwisata oleh Desa Adat Penglipuran. Pertama, pengembangan pariwisata dilakukan dengan menyerahkan pengelolaannya kepada lembaga pengelola. Kedua, pengembangan pariwisata memberikan dampak positif maupun negatif terhadap Desa Penglipuran. Terkait dengan persoalan 
tersebut, maka penelitian ini penting dilakukan untuk mengetahui bentuk dan dampak dari pengembangan pariwisata berbasis desa adat di Desa Penglipuran.

\section{Pokok Permasalahan}

Berdasarkan latar belakang di atas, permasalahan dalam penelitian ini difokuskan pada bentuk dan dampak pengembangan pariwisata berbasis desa adat di Desa Penglipuran Kabupaten Bangli. Permasalahan tersebut akan dipahami dengan menjawab pertanyaan penelitian yang diformulasikan sebagai berikut.

1. Bagaimana bentuk pengembangan pariwisata berbasis desa adat di Desa Penglipuran Kabupaten Bangli ?

2. Bagaimana dampak pengembangan pariwisata berbasis desa adat di Desa Penglipuran Kabupaten Bangli ?

\section{Tujuan Penelitian}

Berdasarkan latar belakang dan rumusan masalah di atas maka dapat dikemukakan tujuan penelitian ini adalah sebagai berikut.

1. Ingin mengetahui bentuk pengembangan pariwisata berbasis desa adat di Desa Penglipuran Kabupaten Bangli.

2. Ingin mengungkapkan seberapa jauh dampak pengembagan pariwisata berbasis desa adat di Desa Penglipuran Kabupaten Bangli

\section{Metode Penelitian}

Lokasi penelitian dilakukan di Desa Adat Penglipuran, Kecamatan Bangli, Kabupaten Bangli. Jenis data yang digunakan adalah data kualitatif yang perolehan datanya bersumber dari data primer dan sekunder. Teknik pengumpulan data adalah dengan menggunakan teknik observasi, wawancara, studi kepustakaan dan dokumentasi. Data yang diperoleh dianalisis secara deskriptif kualitatif dengan menggambarkan keadaan Desa Penglipuran sehingga memperoleh pemahaman mengenai pengembangan pariwisata berbasis desa adat. Analisis data dilakukan melalui tiga alur kegiatan secara bersamaan sebagaimana yang dilakukan Miles dan Huberman (1992: 17-19), yaitu reduksi data, penyajian data dan penarikan kesimpulan.

\section{Hasil dan Pembahasan}

\subsection{Pengembangan Pariwisata}

\section{Berbasis Desa Adat}

Pengembangan pariwisata berbasis desa adat meliputi daya tarik wisata di Desa Penglipuran, bentuk pengembangan pariwisata berbasis desa adat, dan peran desa adat dalam pengembangan pariwisata di Desa Penglipuran. Pertama, daya tarik wisata di Desa Penglipuran terdiri atas daya tarik wisata alam berupa hutan kayu dan hutan bambu dimana keberadaan hutan kayu maupun hutan bambu tersebut dapat memberikan udara pedesaan yang sejuk dan segar. Daya tarik wisata budaya meliputi pola tata ruang desa dengan arsitekturnya yang khas, tugu pahlawan, serta kehidupan masyarakat dengan adat istiadatnya yang unik seperti adanya larangan bagi masyarakat untuk berpoligami. Daya tarik wisata khusus yakni berupa event-event khusus yang diselenggarakan oleh badan pengelola desa wisata seperti Penglipuran Village Festival dan paket wisata khusus bagi wisatawan.

Kedua, bentuk pengembangan pariwisata berbasis desa adat terdiri atas sejarah pengembangan Desa Wisata Penglipuran yang diawali dari Surat Keputusan Bupati Bangli Nomor 115 Tahun 1993 tentang Penetapan Objekobjek Wisata Daerah Kabupaten Bangli. 
Dengan ditetapkannya Desa Penglipuran sebagai objek wisata, maka Pemerintah Kabupaten Bangli mengeluarkan Keputusan Bupati Kepala Daerah Tingkat II Bangli nomor 116 tahun 1993 tentang Penunjukkan Desa Adat Penglipuran Sebagai Petugas Pungut Retribusi Wisata. Mengingat beban prajuru desa adat yang semakin kompleks sedangkan pengelolaan pariwisata perlu dikelola secara profesional, maka pada tanggal 1 Mei 2012 Desa Adat Penglipuran membentuk lembaga pengelola yang bernama Lembaga Pengelola Desa Wisata Penglipuran (Profil Desa Wisata Penglipuran, 2013: iv). Lembaga ini berada dibawah naungan desa adat dan bertanggung jawab penuh kepada desa adat. Susunan kepengurusan Lembaga Pengelola Desa Wisata meliputi Ketua, Wakil Ketua, Administrasi, Bagian Pengembangan Objek, Bagian Operasional, dan dibantu oleh beberapa seksi. Distribusi hasil pengelolaan Desa Wisata Penglipuran bersumber dari tiket masuk wisatawan dengan pembagian retribusi $40 \%$ untuk Desa Adat Penglipuran dan 60\% untuk Pemerintah Kabupaten Bangli.

Ketiga, Desa Adat Penglipuran memiliki peran yang sangat penting dalam dalam pengembangan pariwisata. Hal ini dapat dicermati dari kedudukan desa adat dalam lembaga pengelola desa wisata yakni sebagai dewan pembina yang memiliki wewenang untuk memutuskan segala sesuatu yang terkait dengan pengembangan pariwisata. Dengan keterlibatan desa adat dalam lembaga pengelola, menunjukkan bahwa desa adat tidak hanya memiliki kemampuan untuk mengelola kegiatankegiatan adat dan keagamaan tetapi juga memiliki kemampuan untuk mengelola hal-hal yang bersifat modern seperti kegiatan pariwisata.

\subsection{Dampak Pengembangan Pariwisata Berbasis Desa Adat \\ Dampak pengembangan} pariwisata berbasis desa adat di Desa Penglipuran meliputi dampak pariwisata terhadap lingkungan fisik dan alam, sosial budaya, dan ekonomi. Pertama, dampak pariwisata terhadap lingkungan fisik dan alam berupa dampak positif yaitu terpeliharanya kebersihan lingkungan dan terjaganya keistimewaan lingkungan seperti hutan kayu dan hutan bambu. Sedangkan dampak negatifnya adalah pembukaan pekarangan rumah untuk kios-kios souvenir dan warungwarung. Keberadaan beberapa kios dan warung yang dibuat dengan membuka sebagian tembok penyengker bagian depan pekarangan (di sebelah angkulangkul) menyebabkan keindahan lingkungan menjadi terganggu. Perkembangan pariwisata di Desa Penglipuran juga memberikan dampak terhadap menjamurnya rumah-rumah penginapan (home stay). Pembangunan ini pada umumnya dilakukan dibelakang rumah penduduk yang dulunya berfungsi sebagai teba. Dengan adanya pembangunan tersebut, sebagian dari teba ini tidak lagi berfungsi sebagai kawasan terbuka hijau tetapi sudah dikembangkan tidak hanya dijadikan penginapan (home stay), tetapi di antaranya juga dijadikan rumah tinggal, garasi, dan tempat usaha.

Kedua, dampak pariwisata terhadap sosial budaya meliputi dampak positif yaitu terpeliharanya bangunanbangunan yang menyimpan nilai-nilai budaya serta tempat-tempat bersejarah, dan terpeliharanya kebudayaan tradisional seperti seni, tarian, dan adatistiadat. Pengembangan pariwisata juga berdampak terhadap pendidikan masyarakat baik secara formal maupun 
non formal. Sedangkan dampak negatifnya adalah adanya komersialisasi budaya berupa kecenderungan terjadinya perubahan terhadap keberadaan tempat suci dan bangunan seperti tempat suci yang dulunya hanya difungsikan sebagai tempat upacara keagamaan bagi masyarakat Desa Penglipuran namun sekarang telah menjadi konsumsi bagi para wisatawan yakni wisatawan diperbolehkan memasuki pura walaupun diwajibkan mentaati aturan yang telah ditentukan.

Ketiga, dampak pariwisata terhadap bidang ekonomi meliputi dampak positif yakni (1) terbukanya lapangan pekerjaan baru, (2) meningkatkan taraf hidup dan pendapatan masyarakat, (3) membantu menanggung beban pembangunan sarana dan prasarana di Desa Penglipuran, dan (4) meningkatkan kemampuan manajerial serta ketrampilan masyarakat Desa Penglipuran. Sedangkan dampak negatifnya adalah pendapatan masyarakat tidak tetap, tetapi hanya bersifat musiman yang menyebabkan terjadinya pendapatan yang fluktuatif (naik dan turun) yakni pada musim libur atau hari raya, pendapatan masyarakat meningkat namun pada hari-hari biasa pendapatannya stabil bahkan menurun. Selain itu, pengembangan pariwisata juga menimbulkan persaingan diantara masyarakat. Hal ini tidak dapat dihindari karena dalam suasana masyarakat yang hidup berekonomi, pasti akan selalu ada persaingan sesama rekan seusaha.

\section{Simpulan}

Berdasarkan penjelasan diatas dapat disimpulkan hal-hal sebagai berikut. Pertama, bentuk pengembangan pariwisata berbasis desa adat di Desa Penglipuran Kabupaten Bangli adalah berbentuk badan pengelola yang disebut
Lembaga Pengelola Desa Wisata Penglipuran. Lembaga ini memberikan peran penting kepada Desa Adat Penglipuran yakni sebagai dewan pembina yaitu memberikan arahan kepada pengelola dan memberikan masukan serta solusi atas persoalan yang dihadapi oleh pengelola. Selain itu Desa Adat juga memiliki wewenang untuk memutuskan segala sesuatu yang terkait dengan pengembangan pariwisata. Kedua, dampak pengembangan pariwisata berbasis desa adat di Desa Penglipuran Kabupaten Bangli meliputi dampak positif dan negatif terhadap lingkungan fisik dan alam, sosial budaya masyarakat, dan ekonomi.

\section{Daftar Pustaka}

Biro Humas \& Protokol Setwilda Tingkat I. 1998. Pariwisata Untuk Bali Konsep dan Implementasi Pariwisata Berwawasan Budaya. Denpasar.

Dwijendra, Ngakan Ketut Acwin. 2009. Arsitektur \& Kebudayaan Bali Kuno. Denpasar: Udayana University Press.

Koentjaraninggrat. 2003. Pengantar Antropologi I. Jakarta: PT Rineka Cipta.

Miles, Matthew; A Michael Huberman. 1992. Analisis data Kualitatif. Jakarta UI Press.

Pujaastawa, I.B.G. 2009. Buku Ajar Antropologi Pariwisata.

Denpasar: Program Studi Antropologi Fakultas Sastra Universitas Udayana.

Reuter, Thomas A. 2005. Custodians Of The Sacred Mountains. Jakarta: Yayasan Obor Indonesia.

Profil Desa Wisata Penglipuran, BangliBali 2013 